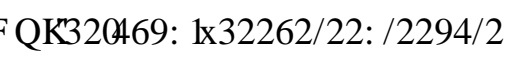

\title{
BLOCK MAINTENANCE POLICY OF MULTI- COMPONENT SYSTEMS WITH ECONOMIC DEPENDENCY
}

\section{POLITYKA OBSEUG BLOKOWYCH WIELOELEMENTOWYCH SYSTEMÓW EKSPLOATACJI Z ZALEŻNOŚCIĄ EKONOMICZNĄ}

\author{
Anna Jodejko \\ Wroclaw University of Technology, Faculty of Mechanical Engineering \\ Politechnika Wroclawska, Wydzial Mechaniczny \\ 50-370 Wroclaw Wybrzeże Wyspiańskiego 27 \\ e-mail: anna.jodejko@pwr.wroc.pl
}

\begin{abstract}
The article proposes a simple algorithm to define parameters of block maintenance policy of multi-unit systems composed of elements with economic dependency. The procedure may be used especially in the case when elements of a system are not identical in the sense of their probability characteristics and analytical solution is inaccessible.
\end{abstract}

Keywords: block replacement policy, maintenance decision, economic dependency, availability

Streszczenie: Opracowanie zawiera algorytm, który pozwala wyznaczyć parametry polityki wymian grupowych $\mathrm{w}$ systemie $\mathrm{z}$ zależnością ekonomiczna. Procedura ma zastosowanie $w$ systemach o niejednorodnych elementach. Kryterium optymalizacji jest minimalizacja kosztów i maksymalizacja gotowości systemu.

Slowa kluczowe: strategia wymian blokowych, decyzje obsługowe, zależność ekonomiczna, gotowość 


\section{BLOCK MAINTENANCE POLICY OF MULTI-COMPONENT SYSTEMS WITH ECONOMIC DEPENDENCY}

\section{Introduction}

An appropriate maintenance policy may have great benefits for every technical system. Many of them consist of a great number of elements. That is why multi-unit maintenance policy is concerned with the optimal strategy for the system as a whole not for every element or for a group of elements. Such an approach is necessary when machines or pieces of equipment depend on each other and single element maintenance models seem useless and should not be used [4]. As a result, correct maintenance policy determination is not an easy task. The complexity of the problem grows when elements of the multi-unit system are not identical in any sense, e.g. their probability characteristics, criticality for the system availability or importance for its economy

\section{Maintenance strategies of multi-component system}

The survey of maintenance models for multi-unit systems may be found in well known literature, e.g.: [4], [6], [11], [12], [14]. Basic strategies, often applied in multi-unit systems, are: group/block/opportunistic maintenance policies with their modifications. They assume that some maintenance activities may be joined together in order to achieve some benefits coming from system internal dependencies [11]: economic, stochastic or structural. Each kind of policy has its good and bad points. The most important goals of planned maintenance activities are:

- to prevent system failures, which may cause unnecessary economic, availability or safety consequences,

- to be ready for maintenance action (e.g. to provide enough spare parts quantity or repair capacity).

On the other hand maintenance actions realized on a system in a good condition may generate extra. That is why a right maintenance model should balance all possible advantages and disadvantages. Some examples of the block/group replacements models may be found in: [2], [3], [7], [13] and opportunistic maintenance models in: [1], [5].

The simplest and the most wasteful policy of preventive maintenance is the block maintenance policy. It assumes that groups of units 
in the system are replaced at periodic intervals but each unit is also replaced/perfectly repaired upon failure [4]. The strategy may be implemented if some kind of dependency between elements exists and it is difficult to monitor the age and the condition of every component. Usually elements are grouped in blocks when they constitute some entirety e.g. a whole subsystem of the system. Another way is to replace together all identical elements in the system. Because of the complexity of the problem, there are few other propositions on how to combine elements in blocks. The task is especially difficult when system components have various probability characteristics and they do not constitute any particular entirety. The number of possible solutions is usually huge and analytical optimisation models are inaccessible. There is still a need to develop easily applied methods, which allow us to find parameters of a "good" solution within a large number of possibilities. Such an attempt is made in the next chapter. The proposed algorithm may be used when one needs to define parameters of block maintenance policy in a system composed of non-identical components.

\section{Block maintenance policy of a system with economic dependency}

This chapter contains a contribution to a block maintenance policy of a heterogeneous, series system with economic dependency. Such kind of dependency usually exists in a continuous working system, when the replacement of a few components together may reduce total cost and/or time of maintenance activities. This kind of interdependencies makes block policy reasonable. The algorithm presented in this section proposes a simple procedure for element grouping. It takes into consideration two optimisation criteria: maintenance cost and a system availability. The basis to start a search is a single element age replacement policy (ARP).

\subsection{Age replacement policy}

The analysed system is composed of $M$ elements. All elements may have various probability characteristics. Time to failure of every element is random and may be described by c.d.f. $F_{i}(t)$, where $i=1,2, \ldots, M$. Block replacement policy in the system is applied. All elements are replaced or perfectly repaired at failure and at moments $k \cdot T_{i},\left(k=1,2, \ldots, \infty ; T_{i}\right.$ - time interval between two consecutive preventive replacements of $i$ th element). Preventive replacement time $T_{w}$ is constant and independent on the number of replaced components. Corrective replacement time after $i$ th element failure is $T_{u i}$. The system incurs failure cost $k_{u}$, when any element of the 
system fails, $k_{w} / n_{i}$ cost of preventive replacement ( $k_{w}$ - single preventive replacement cost, $n_{i}$ - number of elements replaced together with $i$ th element). The cost of the new component purchase (spare part) is $k_{z i}$. The cost $k_{w} / n_{i}$ of preventive replacement represents an economy of scale (economic dependency) in the system.

Every $i$ th element is characterised by variable: $F_{i}(t), T_{i}, T_{u i}, n_{i}, k_{z i}$.

If elements are independent, the best time interval between two preventive replacements may be obtained according to the well known formula of ARP [10], [16]. A modified expression taking into consideration the cost of the new element purchase is [9]:

$$
K_{i}=\frac{k_{u} \cdot F_{i}\left(T_{i}^{*}\right)+k_{w} \cdot\left(1-F_{i}\left(T_{i}^{*}\right)\right)+k_{z}}{\int_{0}^{T_{i}^{*}}\left(1-F_{i}(t)\right) d t},
$$

$T_{i}^{*}$ is optimal time interval between two consecutive preventive replacements of $i$ th element (according to ARP model). It may easily be obtained thanks to numerical methods for various probability distributions [10]. The vector of optimal times, where $T_{1}{ }^{*} \leq T_{2}{ }^{*} \leq T_{i}{ }^{*} \leq T_{M}{ }^{*}$ is the starting point for element grouping. The total cost per unit time that the system incurs, is:

$$
K=\sum_{i=1}^{M} K_{i},
$$

If the individual ARP policy is applied, the availability ratio $A$ of a series system results from the availability of its components $A_{i}$ [8]:

$$
A=\prod_{i=1}^{M} A_{i}=\prod_{i=1}^{M}\left[1+\frac{T_{u i} \cdot F_{i}\left(T_{i}^{*}\right)+T_{w} \cdot\left(1-F_{i}\left(T_{i}^{*}\right)\right)}{\int_{0}^{T_{i}^{*}}\left(1-F_{i}(t)\right) d t}\right]^{-1}
$$

In the case of block replacement policy, the availability ratio of the assumed system with economic dependency changes:

$$
A=\prod_{i=1}^{M} A_{i}=\prod_{i=1}^{M}\left[1+\frac{T_{u i} \cdot F_{i}\left(T_{i}^{*}\right)+\frac{T_{w}}{n_{i}}}{\int_{0}^{T_{i}^{*}}\left(1-F_{i}(t)\right) d t}\right]^{-1}
$$




\subsection{The algorithm of element grouping}

The decision how to join various elements of a system in blocks is a difficult task. The problem is caused by the great number of possible solutions. An analytical optimisation is usually impossible or very hard. That is why simple methods of maintenance activities grouping should be created. The proposed algorithm is built on the base of the individual ARP policy. The search process assumes estimation of potential profit if two elements of the system are replaced/repaired together. The time interval $T_{i}$ of $i$ th component may be reduced or extended only to the nearest value: $T_{i-1}$ or $T_{i+1}$. Only one, the most profitable shift of $T_{i}$ is possible during a single step of the algorithm realization. The procedure stages are following:

a) Estimation of financial profit if $i$ th element time interval $T_{i}{ }^{*}$ is reduced or extended to the nearest available value: $T_{i-1}{ }^{*}$ and $T_{i+1}{ }^{*}$ (fig. 1).

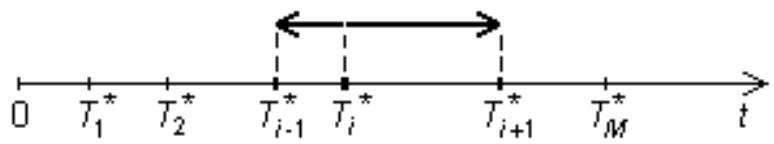

Fig. 1. Possible reduction and extension of time interval $T_{i}^{*}$ for $i$ th element

Profit estimation should consider the cost of the present solution (the present vector of intervals $T_{i}$ ) and the solution after change of $T_{i}$ value. The following equations describe the savings resulting from shortening of time $T_{i}^{*}$ to time $T_{i-1}{ }^{*}$ :

$$
\begin{aligned}
& \Delta K_{i-}=\Delta K_{u i-}+\Delta K_{w i-}+\Delta K_{z i-}, \\
& \Delta K_{u i-}=k_{u}\left(\frac{F_{i}\left(T_{i}^{*}\right)}{\bar{T}_{i}}-\frac{F_{i}\left(T_{i-1}^{*}\right)}{\bar{T}_{i-1}}\right), \\
& \Delta K_{w-}=k_{w}\left(\frac{1-F_{i}\left(T_{i}^{*}\right)}{n_{i} \cdot \bar{T}_{i}}-\frac{1-F_{i}\left(T_{i-1}^{*}\right)}{n_{i-1} \cdot \bar{T}_{i-1}}\right), \\
& \Delta K_{z i-}=k_{z i}\left(\frac{\bar{T}_{i-1}-\bar{T}_{i}}{\bar{T}_{i} \cdot \bar{T}_{i-1}}\right), \\
& \bar{T}_{i}=\int_{0}^{T_{i}^{*}}\left(1-F_{i}(t)\right) d t, \bar{T}_{i-1}=\int_{0}^{T_{i-1}^{*}}\left(1-F_{i}(t)\right) d t .
\end{aligned}
$$


$\Delta K_{i-}$ is the total profit (cost savings) of the system resulting from shortening of time $T_{i}^{*}$ to time $T_{i-1}{ }^{*}, \Delta K_{u i-}$ is the profit resulting from lower failure probability, $\Delta K_{w i-}$ is the loss of profit resulting from higher probability of preventive replacement, $\Delta K_{z i-}$ is the loss of profit resulting from an increase in the number of element purchases, $F_{i}\left(T_{i}{ }^{*}\right)$ is the c.d.f. of time to failure value of $i$ th element in $T_{i}^{*}$ moment, $F_{i}\left(T_{i-1}{ }^{*}\right)$ is the c.d.f. of time to failure value of $i$ th element in $T_{i-1}{ }^{*}$ moment, $n_{i}$ is the number of elements replaced preventively together with $i$ th element, if the element is replaced at $T_{i}{ }^{*}$ moment (present group) and $n_{i-1}$ is the number of elements replaced preventively together with $i$ th element, if the element is replaced at $T_{i-1}{ }^{*}$ moment (group after $T_{i}^{*}$ reduction).

The potential profit of extension of time $T_{i}{ }^{*}$ to time $T_{i+1}{ }^{*}$ should be calculated analogously

b) Estimation of the system availability increase if $i$ th element time interval $T_{i}{ }^{*}$ is reduced or extended to the nearest available value: $T_{i-1}{ }^{*}$ and $T_{i+1}{ }^{*}$. In the case of $T_{i}^{*}$ reduction:

$$
\begin{aligned}
& \Delta A_{i}=\left[1+\frac{T_{u i} \cdot F_{i}\left(T_{i-1}\right)+\frac{T_{w}}{n_{i-1}}}{\int_{0}^{T_{i-1}^{*}}\left(1-F_{i}(t)\right) d t}\right]^{-1}-\left[1+\frac{T_{u i} \cdot F_{i}\left(T_{i}\right)+\frac{T_{w}}{n_{i}}}{\int_{0}^{T_{i}^{*}}\left(1-F_{i}(t)\right) d t}\right]^{-1} \\
& \Delta A_{i-}=\Delta A_{i} \cdot \prod_{j=1 ; j \neq i}^{M} A_{j}
\end{aligned}
$$

$\Delta A_{i}$ is the increase of $i$ th element availability, $\Delta A_{i-}$ is the increase of the system availability resulting from the shortening of time $T_{i}^{*}$ to time $T_{i-1}{ }^{*}, T_{u i}$ is corrective replacement time if $i$ th element fails, $T_{w}$ is preventive replacement time.

The availability increase if $T_{i}^{*}$ is extended should be calculated analogously.

c) Calculation of total profitability of every $T_{i}^{*}$ reduction:

$$
\Delta P_{i-}=\left\{\begin{array}{cl}
-1 \cdot \Delta A_{i-} \cdot \Delta K_{i-} & \text { if } \Delta A_{i-}<0 \cap \Delta K_{i-}<0 \\
\Delta A_{i-} \cdot \Delta K_{i-} & \text { in other cases }
\end{array}\right.
$$

Profitability of $T_{i}^{*}$ extension should be calculated in the same way.

d) If the reduction or extension of any $T_{i}^{*}$ is profitable $\left(\Delta P_{i_{-}}>0\right.$ or $\left.\Delta P_{i^{+}}>0\right)$, maximum benefit should be found:

$P=\left(\max \left(\Delta P_{i-}, \Delta P_{i+}\right)\right)$, 
The time interval $T_{i}^{*}$ of the element with maximum profit should be:

- shortened into $T_{i-1}{ }^{*}$, if $P=\Delta P_{i \text { - }}$,

- lengthened into $T_{i+1}{ }^{*}$, if $P=\Delta P_{i+}$,

and the previous step (a) should be repeated.

e) If $P \leq 0$, there is no further possibility to obtain a better solution.

\section{Numerical example}

In order to present the effect of the presented algorithm, a numerical example was executed (tab.1). The considered system is composed of $M=5$ elements. The time to failure of $i$ th element is described by Weibull c.d.f. with shape parameter $A_{i}$ : and scale parameter $B_{i}$. Values of assumed parameters and costs are following: $A_{i}=\{3,3 ; 3,3 ; 3,3 ; 3,3 ; 3,3\}$, $B_{i}=\{100 ; 200 ; 300 ; 400 ; 500\}, k_{u}=30, k_{w}=1, k_{z i}=\{0,0,0,0,0\}$, $T_{i}{ }^{*}=\{28,56,84,112,140\}, T_{f}=\{30,30,30,30,30\}, T_{p}=1$.

Table 1. Steps of element grouping process

\begin{tabular}{|c|c|c|c|c|c|}
\hline \multicolumn{7}{|c|}{ Step $1, K=0,18, A=0,89$} \\
\hline$T_{i}^{*}$ & 28 & 56 & 84 & 112 & 140 \\
\hline$P$ & - & $1 \mathrm{E}-04$ & - & - & - \\
\hline \multicolumn{7}{|c|}{ Step $2, K=0,09, A=0,91$} \\
\hline$T_{i}^{*}$ & 28 & 28 & 84 & 112 & 140 \\
\hline$P$ & - & - & - & $5 \mathrm{E}-05$ & - \\
\hline \multicolumn{7}{|c|}{ Step $3, K=0,08, A=0,92$} \\
\hline$T_{i}^{*}$ & 28 & 28 & 84 & 84 & 140 \\
\hline$P$ & - & - & - & - & $4 \mathrm{E}-05$ \\
\hline \multicolumn{7}{|c|}{ Step $4, K=0,07, A=0,93$} & \\
\hline$T_{i}{ }^{*}$ & 28 & 28 & 84 & 84 & 84 \\
\hline$P$ & - & - & - & - & - \\
\hline
\end{tabular}

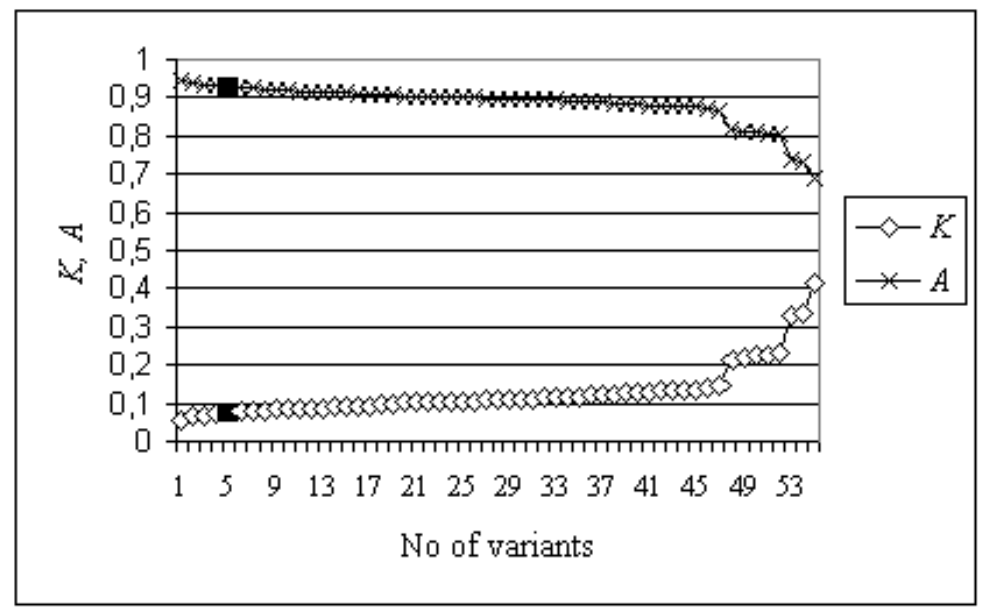

Fig. 2. Total cost per unit time for various variants of grouping 
In order to assess the algorithm results, all 55 possibilities of grouping for the presented 5-elements system were examined. Total cost per unit time that the system incurs and the system availability ratio for various variants of grouping is presented in fig. 2. The solution obtained according to the procedure is marked by $\mathbf{m}$

The same analysis was executed for 15 various vectors of $k_{z i}$. The mean value of solutions obtained according to individual ARP optimization is $40 \%$ (the worst - $75 \%$ ) higher than the cheapest group maintenance policy that was found. The mean solution achieved according to the presented algorithm is $6 \%$ higher and the worst is $26 \%$ higher than the cheapest one.

The algorithm is very sensitive for all model parameters. It always gives much cheaper solution than the individual ARP policy. The availability ratio is always higher than the initial one. Two criteria considered in the procedure cause that every next solution is better than the previous one from the point of view the system economy and availability. It is possible to use the algorithm with only one required criteria. Every next step will shift the solution faster in the direction of cheaper or more reliable solutions.

\section{Conclusion}

Maintenance of systems composed of heterogeneous elements seems to be a challenge for scientists and practitioners. There is a great need to search understandable models and techniques that may be effectively applied in practice. This paper proposes a simple method of heterogeneous element grouping, in series systems with economic dependency. The model can be easily implemented thanks to numerical methods.

The proposed algorithm is a tool, which may be used to define preventive replacement times in systems composed of not identical units. On the basis of single element ARP policy, it allows us to easily find a much better solution of block replacement strategy. It is worth to remember that the found solution is not optimal but in many cases such solution is inaccessible. In order to use the model in practice it should be verified and validated. At the moment the only verification, that was made, is Monte Carlo simulation of the analyzed exploitation process.

\section{References}

1. Archibald T.W., Dekker R. Modified block-replacement for multicomponent systems. IEEE Transactions on Reliability 45(1). 1996. 
2. Castanier B., Grall A., Berenguer C. A condition-based maintenance policy with non-periodic inspections for a two-unit series system. Reliability Engineering and System Safety 87. 2005.

3. Chelbi A., Ait-Kadi D., Aloui H. (2007). Availability optimization for multi-component system subjected to periodic replacement. Aven \& Vinnem (eds). Procc. of ESREL '07. 2007.

4. Cho D.I., Parlar M. A survey of maintenance models for multi-unit systems. European Journal of Operational Res. 51. 1991.

5. Degbotse A.T., Nachlas J.A. Use of nested renewals to model availability under opportunistic maintenance policies. Procc. Annual Reliability And Maintainability Symposium 2003. Tampa. 2003.

6. Dekker R. Applications of maintenance optimization models: A review and analysis. Reliability Engineering and System Safety. 199551.

7. Dekker R., Roelvink I.F.K. Marginal cost criteria for preventive replacement of a group of components. European Journal of Operational Research 84. 1995.

8. Jiang R., Ji P. Age replacement policy: a multi - attribute model. Reliability Engineering and System Safety 76, 2002.

9. Jodejko A. Maintenance problems of technical systems composed of heterogeneous elements. International Journal of Gnedenko e-Forum (in preparation). 2008.

10. Legat V., Zaludova A. H., Cervenka V., Jurca V. Contribution to optimization of preventive replacement. Reliability Engineering and System Safety 51. 1996.

11. Nicolai R.P., Dekker R. A review of multi-component maintenance models. Aven \& Vinnem (eds). Procc. of ESREL '07. Stavanger. 2007.

12. Thomas L.C. A survey of maintenance and replacement models for maintainability and reliability of multi-item systems. Reliability Engineering 16. 1986.

13. Vijnmalen D.J.D., Hontelez J.A.M. Coordinated condition-based repair strategies for component of a multi-component maintenance system with discounts. European Journal of Operational Research 98, 1997.

14. Wang H. A survey of maintenance policies of deteriorating systems. European Journal of Operational Research 139. 2002.

15. Zamojski W. (eds) (1981). Niezawodność $i$ eksploatacja systemów. Politechnika Wrocławska, Wrocław (in polish). 


\section{POLITYKA OBSLUG BLOKOWYCH WIELOELEMENTOWYCH SYSTEMÓW EKSPLOATACJI Z ZALEŻNOŚCIĄ EKONOMICZNĄ}

\section{Wstęp}

Obsługa systemu technicznego jest jednym z czynników warunkujących osiagane przez niego efekty. Wybór właściwej strategii działania jest zwykle skomplikowanym zadaniem, szczególnie jeżeli dotyczy systemów złożonych $\mathrm{z}$ wielu elementów. Sytuacja taka spotykana jest w praktyce najczęściej. Należy wówczas znaleźć politykę obsługową optymalną z punktu widzenia systemu, nie jego poszczególnych elementów. Podejście takie jest konieczne, jeżeli elementy systemu są w jakikolwiek sposób zależne od siebie [4]. Stopień trudności zadania wzrasta jeszcze, gdy części składowe systemu są niejednorodne w jakimkolwiek sensie: charakterystyk niezawodnościowych, znaczenia dla gotowości lub ekonomiki systemu.

\section{Strategie obsług wieloelementowych systemów eksploatacyjnych}

Przegląa modeli obsługi systemów wieloelementowych znaleźć można m.in. w [4], [6], [11], [12], [14]. Strategiami stosowanymi najczęściej są obsługi grupowe/blokowe/okazyjne. Zakładają one profilaktyczny charakter działań i łączenie czynności obsługowych. Powstające w ten sposób korzyści wynikają $\mathrm{z}$ zależności w systemie: ekonomicznej, stochastycznej lub strukturalnej [11]. Główne cele obsług profilaktycznych:

- możliwość zapobiegania uszkodzeniom systemu, które to uszkodzenia powodować mogą niepotrzebne konsekwencje kosztowe, niezawodnościowe lub nawet zagrożenia lub utraty bezpieczeństwa.

- przygotowanie do przeprowadzenia działań obsługowych (np. zapewnienie właściwej liczby elementów wymiennych lub zdolności naprawczych).

Oprócz wspomnianych korzyści, profilaktyczne działania obsługowe moga generować dodatkowe koszty (np. wymiana elementów, które mogłyby pracować dalej). Fakt ten powoduje, że wybór właściwego modelu obsługi systemu eksploatacyjnego powinien wyważyć potencjalne korzyści i straty wynikające z jego zastosowania. Przykłady literaturowych modeli obsługo profilaktycznych systemów wieloelementowych można znaleźć m.in. w [2], [3], [7], [13] (obsługi grupowe/blokowe) lub [1], [5] (obsługi okazyjne). 
Jedną $\mathrm{z}$ najprostszych, jednak najbardziej marnotrawnych strategii obsługowych jest polityka wymian blokowych. Zakłada ona wykonywanie, co określony odcinek czasu wymian grupy elementów, niezależnie od historii poszczególnych $\mathrm{z}$ nich. W przypadku wystąpienia uszkodzenia któregoś z komponentów, jest on wymieniany od razu po uszkodzeniu [4]. Obsługi blokowe stosowane są w przypadku, gdy istnieje zależność między elementami systemu, a stałe monitorowanie wieku poszczególnych części składowych jest niemożliwe lub nieopłacalne. Zwykle grupuje się elementy w bloki elementy jednakowe lub gdy tworzą one pewna całość w systemie (np. podsystem). W pozostałych przypadkach zadanie znacznie się komplikuje. $Z$ reguły, liczba możliwych sposobów grupowania jest bardzo duża, a optymalizacyjne modele analityczne najczęściej są niedostępne. Fakt ten powoduje, że warto ciagle poszukiwać metod, pozwalających w łatwy sposób wybrać „,dobre” parametry polityki obsług. Próba opracowania prostej metody grupowania elementów w bloki została podjęta w niniejszym opracowaniu. Kolejne rozdziały przedstawiają założenia i wyniki osiagane przy wykorzystaniu proponowanej metody.

\section{Polityka wymian blokowych w systemie eksploatacyjnym z zależnością ekonomiczną}

Przykładem systemu eksploatacyjnego z zależnością ekonomiczną może być większość systemów pracujących w ruchu ciągłym. Prowadzenie wspólnych działań obsługowych dla kilku elementów może obniżyć całkowity koszt lub czas przestoju systemu. Zależność ekonomiczna w systemie może uzasadniać korzystanie z polityki obsług blokowych.

Algorytm przedstawiony poniżej pozwala na grupowanie komponentów systemu w bloki, które powinny być obsługiwane łącznie. Procedura uwzględnia dwa kryteria grupowania: sumaryczny koszt działań obsługowych w jednostce czasu oraz poziom gotowości systemu. Punktem startowym do poszukiwania rozwiązania jest polityka obsług według wieku (Age Replacement Policy - ARP) wyznaczona indywidualnie dla wszystkich elementów składowych systemu.

\subsection{Polityka obshug elementów wedtug wieku (ARP)}

Analizowany system, o szeregowej strukturze niezawodności, składa się z $M$ elementów. Czas życia poszczególnych elementów jest losowy i może być opisany funkcją dystrybuanty rozkładu $F_{i}(t)$, gdzie $i=1,2, \ldots, M$. Wszystkie elementy są wymieniane w chwilach $k \cdot T_{i},\left(k=1,2, \ldots, \infty ; T_{i}-\right.$ czas pomiędzy dwoma kolejnymi wymianami profilaktycznymi elementu $i$ ). Czas wymiany profilaktycznej jest stały i nie zależy od liczby 
wymienianych jednocześnie elementów. Czas wymiany korekcyjnej (po uszkodzeniu) $T_{u i}$ jest stały dla pojedynczego elementu. System ponosi koszt $k_{u}$ każdorazowo $\mathrm{w}$ przypadku uszkodzenia oraz koszt wymiany prewencyjnej $k_{w} / n_{i}\left(k_{w}\right.$ - stały koszt jednej wymiany profilaktycznej, $n_{i}-$ liczba elementów wymieniana łącznie z $i$-tym elementem). Koszt zakupu nowego elementu (elementu wymiennego) wynosi $k_{z i}$. Koszt $k_{w} / n_{i}$ wymiany profilaktycznej reprezentuje przypadek zależności ekonomicznej między elementami systemu (ekonomia skali).

Każdy element jest charakteryzowany przez zmienne: $F_{i}(t), T_{i}, T_{u i}, n_{i}, k_{z i}$. $\mathrm{W}$ przypadku, gdy elementy są niezależne od siebie, czas między wymianami profilaktycznymi może być optymalizowany według znanego modelu ARP [10], [16]. Łączny koszt obsługi pojedynczego elementu w jednostce czasu, uwzględniając koszt zakupu elementu ma postać [9]:

$$
K_{i}=\frac{k_{u} \cdot F_{i}\left(T_{i}^{*}\right)+k_{w} \cdot\left(1-F_{i}\left(T_{i}^{*}\right)\right)+k_{z}}{\int_{0}^{T_{i}^{*}}\left(1-F_{i}(t)\right) d t},
$$

$T_{i}^{*}$ oznacza optymalny okres miedzy dwoma wymianami profilaktycznymi $i$-tego elementu (wg ARP). Można go z łatwością uzyskać dzięki metodom numerycznym dla różnych rozkładów prawdopodobieństwa [10]. Wektor optymalnych czasów $T_{i}{ }^{*}$, gdzie $T_{1}{ }^{*} \leq T_{2}{ }^{*} \leq T_{i}{ }^{*} \leq T_{M}{ }^{*}$ jest punktem startowym dla procesu grupowania elementów. Całkowity koszt obsługi systemu w jednostce czasu wynosi:

$$
K=\sum_{i=1}^{M} K_{i}
$$

W przypadku indywidualnej polityki ARP, współczynnik gotowości systemu o szeregowej strukturze niezawodności można obliczyć:

$$
A=\prod_{i=1}^{M} A_{i}=\prod_{i=1}^{M}\left[1+\frac{T_{u i} \cdot F_{i}\left(T_{i}^{*}\right)+T_{w} \cdot\left(1-F_{i}\left(T_{i}^{*}\right)\right)}{\int_{0}^{T_{i}^{*}}\left(1-F_{i}(t)\right) d t}\right]^{-1}
$$

Współczynnik ulega zmianie podczas stosowania polityki wymian blokowych i po uwzględnieniu przyjętej zależności ekonomicznej:

$$
A=\prod_{i=1}^{M} A_{i}=\prod_{i=1}^{M}\left[1+\frac{T_{u i} \cdot F_{i}\left(T_{i}^{*}\right)+\frac{T_{w}}{n_{i}}}{\int_{0}^{T_{i}^{*}}\left(1-F_{i}(t)\right) d t}\right]^{-1}
$$




\subsection{Algorytm grupowania elementów}

Łączenie elementów w bloki jest utrudnione, gdyż liczba możliwych rozwiązań jest bardzo duża. Analityczna optymalizacja jest zwykle niemożliwa lub bardzo trudna. Niezbędne jest zatem poszukiwanie metod, które przy niewielkim nakładzie sił pozwalają wybrać „satysfakcjonujące” rozwiązanie. Przedstawiony algorytm zakłada łączenie czynności obsługowych, w wyniku których zwiększy się gotowość systemu lub koszt obsług zmniejszy się w stosunku do rozwiązania obecnego.

a) Oszacowanie oszczędności finansowych uzyskanych gdyby okres $T_{i}^{*}$ został wydłużony lub skrócony do wartości: $T_{i-1}{ }^{*}$ oraz $T_{i+1}{ }^{*}$ (rys. 1).

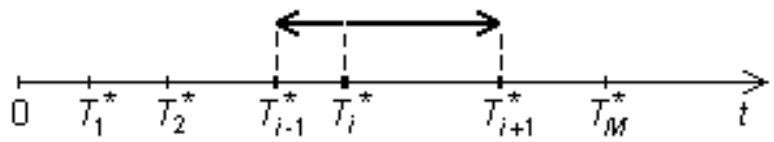

Rys. 1. Możliwość wydłużenia i skrócenia okresu między wymianami profilaktycznymi dla $i$-tego elementu

Potencjalne korzyści wynikające ze zmiany okresu $T_{i}{ }^{*}$ uwzględniają koszty ponoszone przez system przy obecnym rozwiązaniu oraz po zmianie $T_{i}^{*}$. Koszty obsługi systemu w przypadku skrócenia optymalnego okresu między blokowymi wymianami profilaktycznymi można obliczyć:

$$
\begin{aligned}
& \Delta K_{i-}=\Delta K_{u i-}+\Delta K_{w i-}+\Delta K_{z i-}, \\
& \Delta K_{u i-}=k_{u}\left(\frac{F_{i}\left(T_{i}^{*}\right)}{\bar{T}_{i}}-\frac{F_{i}\left(T_{i-1}^{*}\right)}{\bar{T}_{i-1}}\right), \\
& \Delta K_{w-}=k_{w}\left(\frac{1-F_{i}\left(T_{i}^{*}\right)}{n_{i} \cdot \bar{T}_{i}}-\frac{1-F_{i}\left(T_{i-1}^{*}\right)}{n_{i-1} \cdot \bar{T}_{i-1}}\right), \\
& \Delta K_{z i-}=k_{z i}\left(\frac{\bar{T}_{i-1}-\bar{T}_{i}}{\bar{T}_{i} \cdot \bar{T}_{i-1}}\right), \\
& \bar{T}_{i}=\int_{0}^{T_{i}^{*}}\left(1-F_{i}(t)\right) d t, \bar{T}_{i-1}=\int_{0}^{T_{i-1}^{*}}\left(1-F_{i}(t)\right) d t .
\end{aligned}
$$

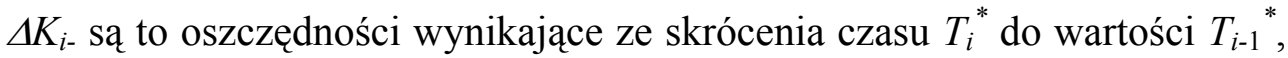
$\Delta K_{u i-}$ oznacza obniżenie kosztu uszkodzenia się $i$-tego elementu, $\Delta K_{w i-}$ jest zmianą łącznego kosztu obsług profilaktycznych, $\Delta K_{z i \text { - }}$ oznacza dodatkowy koszt przeznaczony na nowe elementy wymienne (częstsze obsługi), $F_{i}\left(T_{i}^{*}\right)$ 
jest wartością funkcji zawodności $i$-tego elementu w chwili $T_{i}{ }^{*}, F_{i}\left(T_{i-1}{ }^{*}\right)$ jest wartością funkcji zawodności $i$-tego elementu $\mathrm{w}$ chwili $T_{i-1}{ }^{*}, n_{i}$ oznacza liczbę elementów w grupie, wymienianych wspólnie z $i$-tym elementem co okres $T_{i}^{*}$ (liczność obecnej grupy), $n_{i-1}$ oznacza liczbę elementów w grupie, wymienianych wspólnie z $i$-tym elementem co okres $T_{i-1}{ }^{*}$ (liczność grupy po skróceniu $T_{i}^{*}$ ).

Potencjalny zysk wydłużenia czasu $T_{i}^{*}$ do czasu $T_{i+1}{ }^{*}$ powinien być obliczony analogicznie.

b) Oszacowanie przyrostu gotowości systemu, w przypadku gdyby okres miedzy wymianami $T_{i}{ }^{*}$ został skrócony do czasu $T_{i-1}{ }^{*}$ :

$\Delta A_{i}=\left[1+\frac{T_{u i} \cdot F_{i}\left(T_{i-1}\right)+\frac{T_{w}}{n_{i-1}}}{\int_{0}^{T_{i-1}^{*}}\left(1-F_{i}(t)\right) d t}\right]^{-1}-\left[1+\frac{T_{u i} \cdot F_{i}\left(T_{i}\right)+\frac{T_{w}}{n_{i}}}{\int_{0}^{T_{i}^{*}}\left(1-F_{i}(t)\right) d t}\right]^{-1}$

$\Delta A_{i-}=\Delta A_{i} \cdot \prod_{j=1 ; j \neq i}^{M} A_{j}$

$\Delta A_{i}$ jest przyrostem gotowości $i$-tego elementu, $\Delta A_{i-}$ jest przyrostem gotowości całego systemu wynikającej ze skrócenia czasu $T_{i}^{*}, T_{u i}$ oznacza czas wymiany korekcyjnej $i$-tego elementu, $T_{w}$ jest czasem wymiany profilaktycznej.

Przyrost gotowości systemu dla przypadku wydłużenia czasu $T_{i}^{*}$ obliczyć można analogicznie.

c) Obliczenie łącznych korzyści/strat $\Delta P_{i}$, jakie uzyskałby system w przypadku skrócenia któregokolwiek czasu $T_{i}{ }^{*}$ :

$\Delta P_{i-}=\left\{\begin{array}{cl}-1 \cdot \Delta A_{i-} \cdot \Delta K_{i-} & \text { gdy } \Delta A_{i-}<0 \cap \Delta K_{i-}<0 \\ \Delta A_{i-} \cdot \Delta K_{i-} & \text { w innych przypadkach }\end{array}\right.$.

Korzyści/straty wydłużenia okresu $T_{i}^{*}$ powinny być oszacowane w ten sam sposób.

d) Jeżeli skrócenie lub wydłużenie któregokolwiek czasu $T_{i}{ }^{*}$ jest opłacalne $\left(\Delta P_{i-}>0\right.$ lub $\left.\Delta P_{i^{+}}>0\right)$, należy znaleźć element dający maksymalny zysk:

$P=\left(\max \left(\Delta P_{i-}, \Delta P_{i+}\right)\right)$,

Dotychczasowy interwał czasowy między wymianami profilaktycznymi $T_{i}^{*}$ dla elementu o maksymalnej opłacalności powinien zostać:

- skrócony do wartości $T_{i-1}{ }^{*}$, jeżeli $P=\Delta P_{i \text {-, }}$

- wydłużony do wartości $T_{i+1}{ }^{*}$, jeżeli $P=\Delta P_{i+}$. 
W kolejnym kroku realizacji algorytmu powracamy do kroku (a).

e) Jeżeli $P \leq 0$, nie ma możliwości uzyskania lepszego rozwiązania.

\section{Przykład obliczeniowy}

W celu prezentacji rezultatów proponowanego algorytmu, zrealizowano proces grupowania (tab. 1) dla założonych danych. Analizowany system składa się z 5 elementów. Czas życia elementów opisany jest rozkładem Weibull'a o parametrach kształtu odpowiednio $A_{i}$ : i parametrach skali $B_{i}$. Przyjęto następujące wartości parametrów rozkładów prawdopodobieństwa i parametrów kosztowych: $A_{i}=\{3,3 ; 3,3 ; 3,3 ; 3,3 ; 3,3\}, B_{i}=\{100 ; 200 ; 300$; $400 ; 500\}, k_{u}=30, k_{w}=1, k_{z i}=\{0,0,0,0,0\}, T_{i}^{*}=\{28,56,84,112,140\}$, $T_{f}=\{30,30,30,30,30\}, T_{p}=1$.

Tabela 1. Etapy procesu grupowania

\begin{tabular}{|c|c|c|c|c|c|}
\hline \multicolumn{7}{|c|}{ Krok $1, K=0,18, A=0,89$} \\
\hline$T_{i}{ }^{*}$ & 28 & 56 & 84 & 112 & 140 \\
\hline$P$ & - & $1 \mathrm{E}-04$ & - & - & - \\
\hline \multicolumn{7}{|c|}{ Krok $2, K=0,09, A=0,91$} \\
\hline$T_{i}{ }^{*}$ & 28 & 28 & 84 & 112 & 140 \\
\hline$P$ & - & - & - & $5 \mathrm{E}-05$ & - \\
\hline \multicolumn{7}{|c|}{ Krok $3, K=0,08, A=0,92$} \\
\hline$T_{i}{ }^{*}$ & 28 & 28 & 84 & 84 & 140 \\
\hline$P$ & - & - & - & - & $4 \mathrm{E}-05$ \\
\hline \multicolumn{7}{|c|}{ Krok $4, K=0,07, A=0,93$} \\
\hline$T_{i}{ }^{*}$ & 28 & 28 & 84 & 84 & 84 \\
\hline$P$ & - & - & - & - & - \\
\hline
\end{tabular}

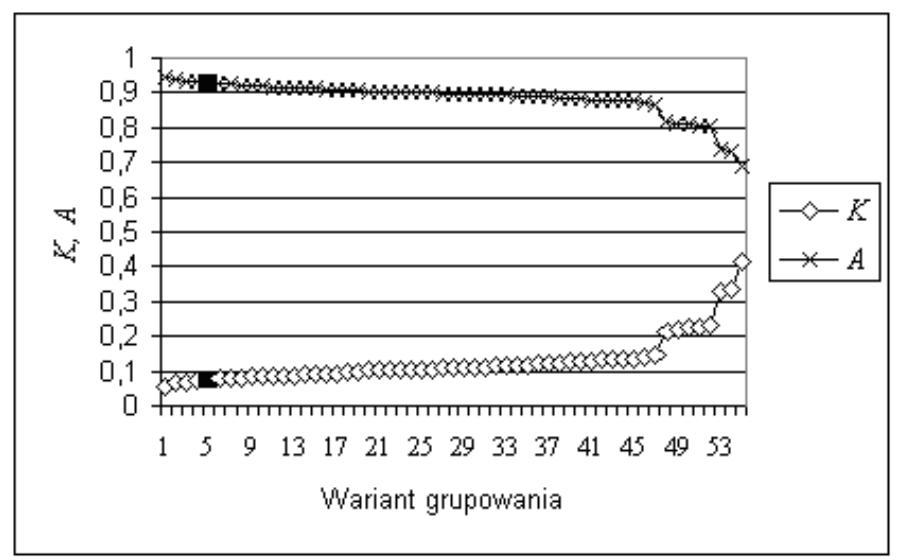

Rys. 2. Całkowity koszt obsługi w jednostce czasu i współczynnik gotowości systemu uzyskany dla różnych wariantów grupowania elementów 
Aby ocenić wyniki procedury, wszystkie 55 możliwych kombinacji grupowania analizowanego 5-elementowego systemu zostały zbadane. Całkowity koszt obsługi systemu i współczynnik gotowości dla różnych wariantów grupowania wymian elementów przedstawiono na powyższym wykresie (rys. 2). Rozwiązanie uzyskane wyznaczone przez algorytm zaznaczone zostało na wykresie symbolem $\mathbf{m}$.

Podobna analiza przeprowadzona została dla 15 różnych wektorów kosztu $k_{z i}$. Średni koszt obsługi systemu, uzyskany wg modelu ARP (bez grupowania) był $40 \%$ wyższy niż najtańsze rozwiązanie, znalezione wśród możliwych 55 wariantów. Rozwiązania uzyskane za pomocą algorytmu grupowania są średnio 6\% droższe niż wariant najtańszy (możliwy do uzyskania z wszystkich 55 możliwych).

Badanie pokazało, że rozwiązania uzyskane za pomocą algorytmu charakteryzują się znacznie niższym kosztem niż indywidualna polityka ARP oraz pozwalają zwiększyć współczynnik gotowości systemu, mimo obniżenia kosztów jego obsług. Algorytm umożliwia korzystanie z pojedynczego kryterium optymalizacji, co pozwala szybciej przesuwać każde kolejne rozwiązanie w kierunku kombinacji tańszych lub o wyższej gotowości.

\section{Podsumowanie}

Obsługa systemów eksploatacyjnych złożonych z niejednakowych elementów, stwarza potrzebę ciagłego rozwoju prostych obliczeniowo metod, które mogłyby być stosowane w praktyce. Przedstawiony algorytm proponuje metodę grupowania działań obsługowych w systemie o szeregowej strukturze niezawodnościowej i elementach zależnych ekonomicznie. Model może być łatwo stosowany dzięki metodom numerycznym nawet w przypadku komponentów o zupełnie odmiennych charakterystykach niezawodnościowych. Warto pamiętać, że wyznaczane rozwiązanie często nie bywa optymalne, jednak bardzo często takie rozwiązanie jest w ogóle niedostępne. Aby stosować model należałoby go jednak zweryfikować w praktyce. Do chwili obecnej model został zweryfikowany jedynie na podstawie wyników uzyskanych z symulacji procesu eksploatacji.

Dr Eng. JODEJKO Anna, Wrocław University of Technology, Faculty of Mechanical Engineering, Division of Logistics and Transportation Systems, specialization: reliability engineering, logistics. 